\title{
SUSTAINABLE FINANCING FOR THE ENTREPRENEURSHIP CONTINUAL GROWTH: A GAP ANALYSIS AMONG SMALL AND MEDIUM ENTERPRISES IN INDIA
}

\author{
Maharaja Alagpuria
}

\begin{abstract}
Considering the existing funding conditionalities in India, the small and medium enterprises have to face stringent norms as sustainable financing requirements based on Environment, Society and Governance (ESG) disclosures are becoming mandatory for every organization worldwide. The onus still turns to be more intense than ever for the small and medium enterprises (SMEs). The main purpose of this paper is to warn SMEs of the upcoming sustainable financing conditionalities and develop a clear understanding among the SMEs on why they should adapt sustainable financing norms and be resilient towards sustainable financing and ESG disclosures. This paper also tends to inspire SMEs for entrepreneurial growth by striking a balance between their financial requirements and mandatory obligations to benefit themselves, society and the Indian economy. Moreover, this paper focuses on the conceptual stipulation and early adaption of sustainable finance framework by the SMEs and strives to fathom the gap between the sustainable financing realities and the expected level of SMEs' exposure to sustainable financing and mandatory ESG disclosures. The research methodology identifies seven such areas interconnecting the sustainable financing and UN sustainable development goals (SDGs); Environment (Climate action \& Carbon tax), Society (Sustainable Consumption \& Externalities), Business (Sustainable Production) and Governance (Green finance, \& ESG disclosures) and investigates to find the gap between the perception and expectation of SMEs about the mandatory requirements for sustainable financing and sustainability adaption in India.
\end{abstract}

Keywords: Sustainable Financing, Small and Medium Enterprises, Environment, Society and Governance (ESG), Sustainability Development Goals (SDGs)

JEL Classification: G30, G32, M14

Author:

Maharaja Alagpuria (Corresponding Author)

TIPS School of Management, Coimbatore, India

E-mail:modelimits@gmail.com

https://orcid.org/0000-0002-0866-4034

Citation: Alagpuria, M. (2021). Sustainable Financing for the Entrepreneurship Continual Growth: A Gap Analysis on Small and Medium Enterprises in India. Virtual Economics. 4(2), 105-119. https://doi.org/10.34021/ve.2021.04.02(6)

Received: December 19, 2020. Revised: February 3, 2021. Accepted: April 12, 2021.

(C) Author(s) 2021. Licensed under the Creative Commons License - Attribution 4.0 International (CC BY 4.0) 


\section{Introduction}

The role of small and medium enterprises (SMEs) is huge to the economic development of a nation next to agricultural sector, which constitutes a major source of employment and generates significant domestic and export earnings. India is no exception and a large part of business in the country is done through SMEs. Today, it accounts for nearly $40 \%$ of the gross value of output in the manufacturing sector and over $45 \%$ of the total exports from the country. SMEs need adequate financing from investors, financial institutions and international funding organizations for long term development and expansion to meet funding requirements at each stage of their business development from initiation, operation, development, restructuring, recovery and beyond. To meet the requirements of the business system and further the business growth and opportunities of the companies and businesses, SMEs would have to deploy funds on projects continuously in coordination with the society and governments for implementing various projects to achieve economic development of India.

At present, the world economy is influenced by greater financial transition involving the business firms, corporate, small and medium enterprises. The sustainability lens has started scanning all the business operations to check them for any adverse actions in providing clear directions to connect the investors and the SMEs to arrange credits as and when they need. In this context, not only the corporate companies but also SMEs would have to align their goals with sustainable financing and Sustainability Development Goals (SDGs) of the United Nations. As the role and contribution of SMEs are significant in the economic development of a nation and the future of generations, they must have clear understanding and policy setting on how they have to resort to sustainable production and consumption of the products and services in their operations. The finance providers are looking for sustainable financing policy decisions of the government for setting norms on their investments. Obviously, SME sector emerges as a key instrument in poverty alleviation and unemployment eradication which appears in the first place in the agenda of the UN SDGs.

\section{Literature Review}

Viewing the role of investors in sustainable financing, it could be transparently noticed that the concept of ESG should not be overlooked. All ESG operations must first be tracked and then reported. The reality is that ESG reporting is optional which allows some companies not to report their operational impacts on the society and environment.

Zabri et al. (2021) suggest that enhancing knowledge of appropriate funding sources and access to external finance at an acceptable cost will facilitate greater productivity and growth. A comprehensive review of government and financial institutions' policies to increase access to finance for the microenterprise sector is therefore imperative.

It is very important to finance SMEs' activities. As a matter of social non-sustainability, growing inequality leads to political tensions hampering development (Acemoglu \& Robinson, 2012). 
SMEs face many obstacles when they try to access credit market. These obstacles are increased if the SMEs are innovative. In this case, financial data are insufficient or even not reliable. Thus, building a judgemental rating model is mainly based on qualitative criteria (Angilella \& Mazzù, 2013).

It should also be noted that firm size distributions in developing economies are dominated by micro and small firms. Small firms, especially informal micro firms, are the biggest creators of employment in many of these countries. However, examination of the financing patterns across firm sizes reveals that small firms are more constrained than large firms in their access to external finance. This is important since although informal finance is very prevalent in many economies, at the margin it seems to be bank finance that is associated with firm growth. Overall, research shows that the firms in developing economies are not as productive as those in developed economies (Ayyagari et al., 2012).

Debt financing, especially bank loans (advances), is the main source of funding for small firms; the corporate bond and organized security markets are mainly accessed by large firms in need of long-term financing. Other authors also note that small firms face higher financing obstacles (access to finance and cost of credit) than large firms, thus they are more severely affected when they face financing constraints (Beck et al., 2008).

Brandt et al. (2013) formulate a hypothesis and state that sustainability may imply a challenge to our underlying dominant cultural ideas about nature, science, technology, and society. In this mode, the project proposes that it may be important to engage sustainability through such issues as land use, energy efficiency, urban form, or consumptive behaviour.

Busch et al. (2016) suggest a reorientation toward a long-term paradigm for sustainable investments and ESG data must become more trustworthy. From a theoretical point of view, the authors finally highlight the potential market consequences when ESG investment criteria are used.

Chava (2014) studies the results of exclusionary socially responsible investing and environmentally sensitive lending and suggests that the consequent increase in the cost of equity and debt capital has the potential to prompt firms to internalize their environmental externalities.

Calice et al. (2012) state that the motivation for the interviewed banks to get involved in SMEs financing was to a large extent not driven by the moves of competitors. Almost all banks (81 percent) reported that they did not become involved in SMEs financing because of the need to follow other banks. Finally, 63 percent of the banks were of the opinion that it is important to be one of the first movers in the financing sector.

Financial institutions should develop products that are best suited for small business operators. This will not only benefit small business operators but the nation at large and also the banks themselves in terms of profitability and customer base (Chimucheka, 2013). 
The findings of the study indicate that good corporate ESG performance enhances financial performance evaluated through accounting as well as market-based measures. The findings have practical implications for corporations, investors, regulators, as well as policymakers. The study highlights the need for adoption of sustainability reporting, including disclosure of ESG scores. (Dalal \& Nimit, 2019).

Vegholm (2009) in a study "Understanding Bank - SME Relationships: The influence of Adaptation and Fairness on Customer Satisfaction" highlights that those banks are employing fairness in their strategy and encouraging employees to have relational interaction with SMEs for greater customer satisfaction.

Hamilton \& Fox (1998) viewed as of how the financing preferences of owners are established enables one to explain small firm financial structures without resorting to any shortcomings or gaps in the supply of finance. Indeed, one may even argue that any apparent gap is in part a consequence rather than a cause of the financing preferences of small firm owners.

Sustainable development has the potential to address fundamental challenges for humanity, now and in the future. However, to do this, it needs more clarity of meaning, concentrating on sustainable livelihoods and well-being rather than well-having, and long-term environmental sustainability, which requires a strong basis in principles that link the social and environmental to human equity (Hopwood et al., 2005).

Financial institutions and government role is to develop the small-scale industry by setting of right type of institution, providing infrastructure facility, providing institutional assistance, liberal and sympathetic attitude in formulating and implementing government policies towards small industry (Jain, 1990).

As sustainability science is a problem-driven and solution-oriented field that follows a transformational agenda, transdisciplinary research is, in many cases, a promising choice, as it aims at bridging the gap between problem solving and scientific innovation. But this does not undermine the relevance of disciplinary or interdisciplinary approaches (Lang et al., 2012).

Mercieca et al. (2009) point out in their research paper "Bank Market Structure, Competition and SME Financing Relationships in European Regions" that the competition in the European banking sector has a positive effect on the number of lendings and borrowings and find no strong evidence that these tend to offset each other.

The key messages of the cultural spheres are convergent, and the actors are becoming interconnected. We need to build on the connections created and the progress to ensure culture's ability to support truly sustainable development is fully harnessed by all actors (Pascual, 2021). 
Sandberg (2015) in his book proposes a new theory for a more sustainable role of finance in society. The theory represents an attempt to strike a balance between opposing camps in contemporary business ethics research. Moreover, the chapter discusses implications of the new theory for both public policies and the governance of financial institutions.

While financial institutions have started to avoid unsustainable companies from a risk perspective, the frontrunners are now increasingly investing in sustainable companies and projects to create a long-term value for the wider community. Major obstacles to sustainable finance are short-termism and insufficient private efforts (Schoenmaker, 2017).

The role of finance would play a vital role in allocating investment to sustainable companies and thus accelerate the transition to a low-carbon and circular economy (Schoenmaker \& Schramade, 2019).

The transmission mechanisms between finance and sustainability find that there is no simple one-to-one relationship between financial development and sustainable development. Sustainable finance sets standards to how finance (investing and lending) would interact with economic, social and environmental issues (ESG) (Scholtens, 2006).

Overview of bank financing to SMEs and constraints like asymmetric information, agency issues, risk to lending in small firms, costly monitoring, competition among banks, variability of entrepreneurs prove that entrepreneurs gain from increased project valuations and banks (Storey, 1994).

\section{Methodology}

This paper adapts the descriptive research design, and multiple regression analysis has been used for data analysis to find the gap between the perception and expectation of SMEs on sustainable finance (ESG) criteria interconnecting a few UN sustainable development goals (SDGs); Environment (Climate action \& Carbon tax), Society (Sustainable Consumption \& Externalities) and Governance (Sustainable Production, Green finance \& ESG disclosures). Systematic sampling technique is used to ascertain a sample size of 325 SMEs from Chennai region, Tamil Nadu in India that were contacted directly to get their responses for the analysis. The responses are analysed using SPSS-software to derive results and interpretation. In order to find the outcomes, the association between the SMEs' profile and their level of perception and expectation on the 7 sustainable finance components were analysed. The main objective of this paper is to analyse the gap between the level of perception and expectation on sustainable financing and ESG disclosures among Indian SMEs.

\section{Results and Discussion}

The gap analysis on the SMEs' profiles and their perception and expectation on the 7 sustainable finance components and UN SDGs has been done by using multiple regression analysis. The independent variables are 5 profile components, namely age, educational 
qualification, working experience, number of employees working in the company and annual turnover of SMEs were analysed.

Table 1. The Gap in Perception and Expectation on Climate Action

\begin{tabular}{|c|c|c|c|c|c|}
\hline No. & Variables & Coefficient & SE & 't' value & 'p' value \\
\hline & (Constant) & -0.503 & & & \\
\hline 1. & Age & 0.213 & 0.022 & 9.682 & 0.000 \\
\hline 2. & Educational Qualification & 0.085 & 0.019 & 4.474 & 0.000 \\
\hline 3. & Working Experience & -0.030 & 0.018 & -1.667 & $0.098^{\mathrm{NS}}$ \\
\hline 4. & Number of employees working in the company & 0.090 & 0.027 & 3.333 & 0.000 \\
\hline 5. & Annual Turnover & 0.112 & 0.026 & 4.308 & 0.000 \\
\hline & $R$ Value & 0.961 & & & \\
\hline & $R^{2}$ Value & 0.924 & & & \\
\hline & F Value & 123.887 & & & \\
\hline
\end{tabular}

Source: developed by the author.

Gap on Climate Action $=-0.503+0.213$ (Age) +0.085 (Educational Qualification) -0.030 (Working experience) +0.090 (Number of employees working in the company) +0.112 (Annual Turnover). It is found from the analysis that the age, educational qualification, number of employees working in the company and annual turnover have positive association.

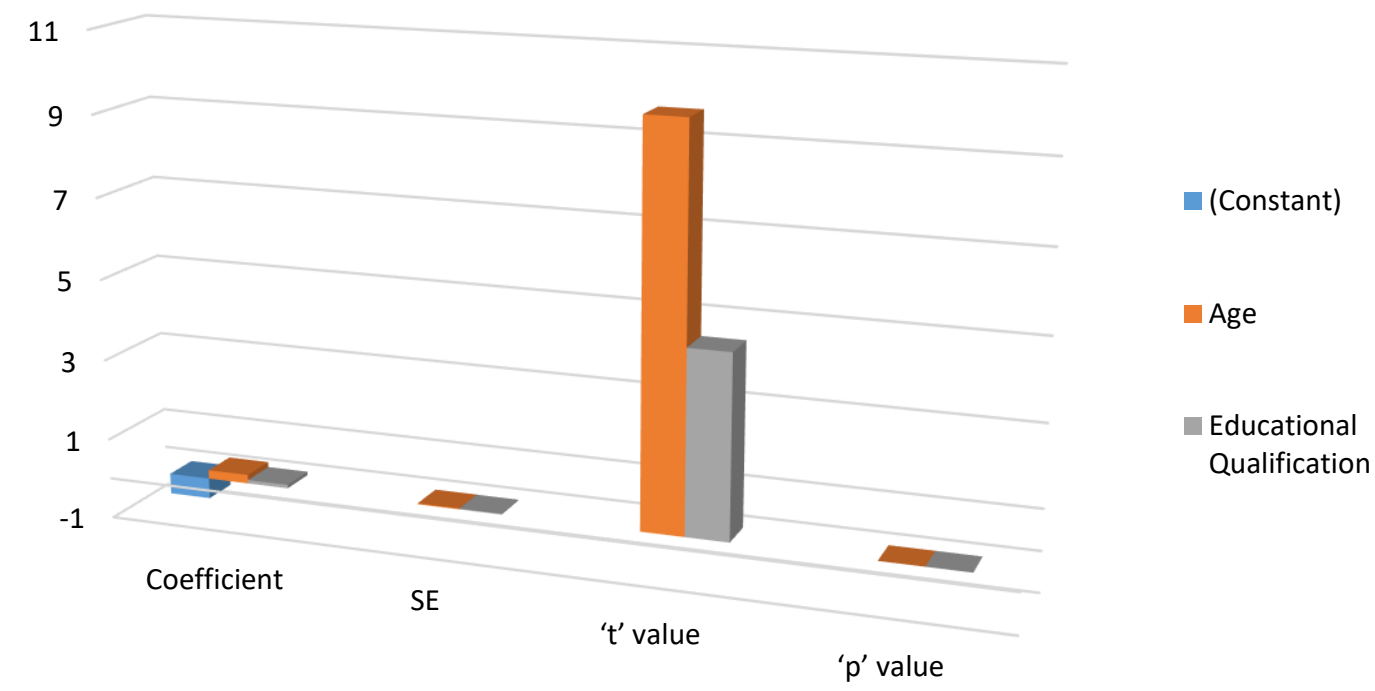

Figure 1. Climate Action

Source: developed by the author on the basis of Table 1 . 
Table 2. The Gap in Perception and Expectation on Carbon Tax

\begin{tabular}{llrrrr}
\hline No. & \multicolumn{1}{c}{ Variables } & Coefficient & SE & ' $\mathbf{t}$ ' value & ' $\mathbf{p}$ ' value \\
\hline & (Constant) & -0.454 & & & \\
\hline 1. & Age & 0.226 & 0.024 & 9.417 & 0.000 \\
\hline 2. & Educational Qualification & 0.107 & 0.021 & 5.095 & 0.000 \\
\hline 3. & Working Experience & 0.201 & 0.019 & 10.579 & 0.000 \\
\hline 4. & Number of employees working in the company & -0.072 & 0.028 & -2.571 & 0.011 \\
\hline 5. & Annual Turnover & 0.131 & 0.028 & 4.679 & 0.000 \\
\hline & R Value & $\mathbf{0 . 9 5 5}$ & & & \\
\hline & $\mathbf{R}$ Value & $\mathbf{0 . 9 1 2}$ & & & \\
\hline & F Value & $\mathbf{3 1 . 3 1 6}$ & & & \\
\hline
\end{tabular}

Source: developed by the author.

Gap on Carbon Tax $=-0.454+0.226$ (Age) +0.107 (Educational Qualification) +0.201 (Working experience) - 0.072 (Number of employees working in the company) + 0.131 (Annual Turnover). It is found from the analysis that the age, educational qualification, working experience and annual turnover have positive association.

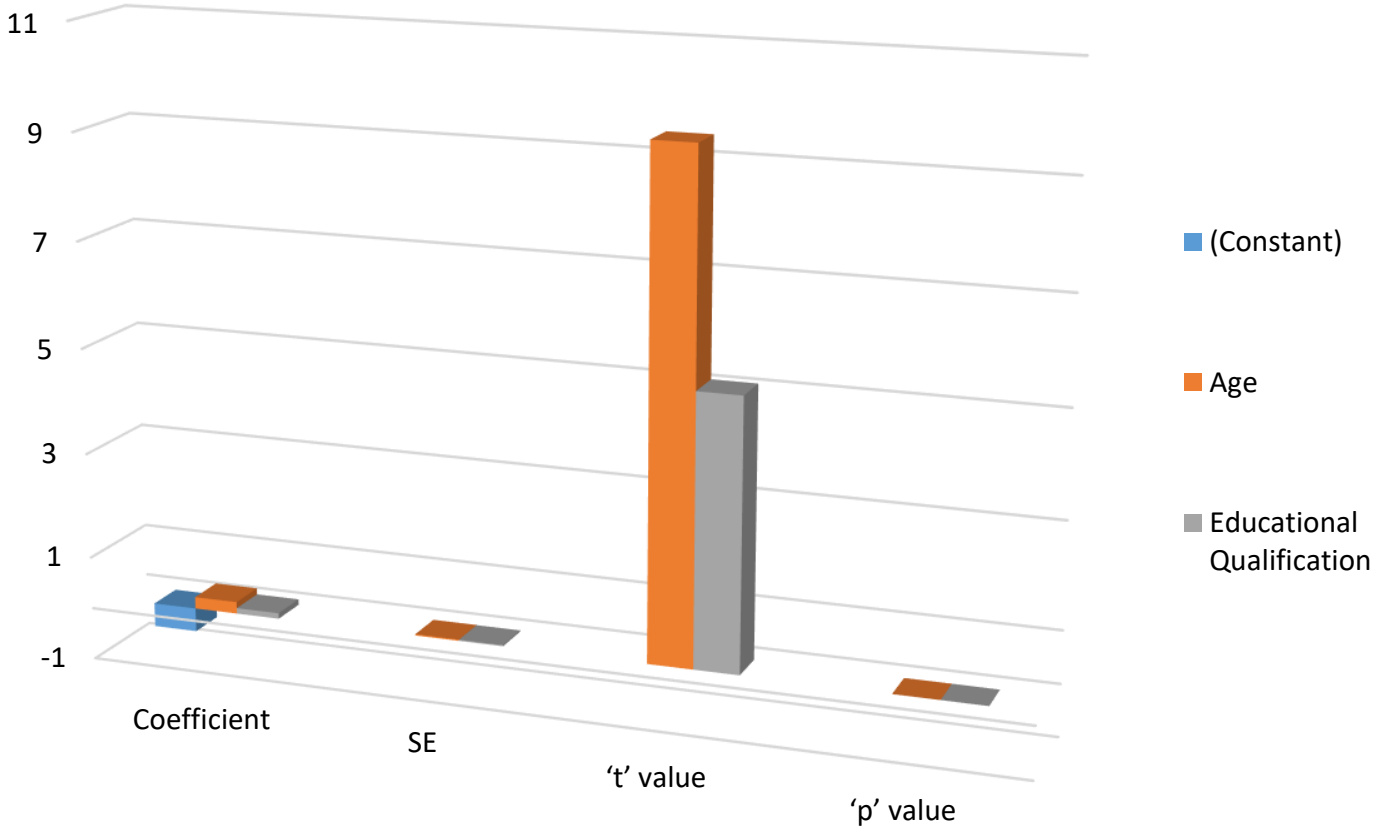

Figure 2. Carbon Tax

Source: developed by the author on the basis of Table 2 . 
Table 3. The Gap in Perception and Expectation on Sustainable Consumption

\begin{tabular}{|c|c|c|c|c|c|}
\hline No. & Variables & Coefficient & SE & 't' value & 'p' value \\
\hline & (Constant) & -0.637 & & & \\
\hline 1. & Age & 0.223 & 0.025 & 8.920 & 0.000 \\
\hline 2. & Educational Qualification & 0.136 & 0.022 & 6.182 & 0.000 \\
\hline 3. & Working Experience & 0.131 & 0.021 & 6.238 & 0.000 \\
\hline 4. & Number of employees working in the company & -0.061 & 0.031 & -1.968 & 0.046 \\
\hline 5. & Annual Turnover & 0.025 & 0.03 & 0.833 & $0.410^{\mathrm{NS}}$ \\
\hline & R Value & 0.975 & & & \\
\hline & $\mathbf{R}^{2}$ Value & 0.951 & & & \\
\hline & F Value & 71.685 & & & \\
\hline
\end{tabular}

Source: developed by the author.

Gap on Sustainable Consumption $=-0.637+0.223($ Age $)+0.136$ (Educational Qualification $)+$ 0.131 (Working experience) - 0.061 (Number of employees working in the company) +0.025 (Annual Turnover). It is found from the analysis that the age, educational qualification and working experience have positive association.

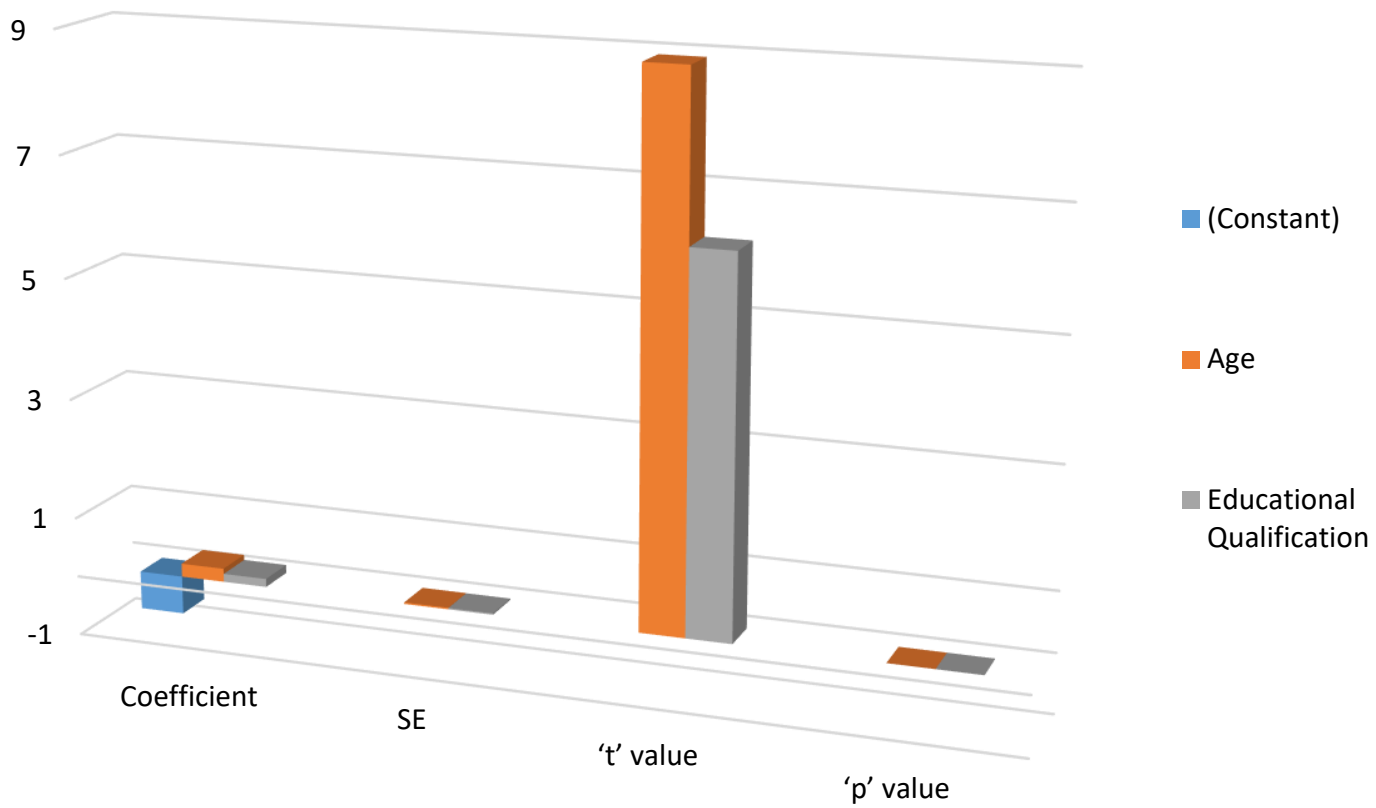

Figure 3. Sustainable Consumption

Source: developed by the author on the basis of Table 3 . 
Table 4. The Gap in Perception and Expectation on Externalities

\begin{tabular}{|c|c|c|c|c|c|}
\hline No. & Variables & Coefficient & SE & 't' value & 'p' value \\
\hline & (Constant) & -0.228 & & & \\
\hline 1. & Age & -0.030 & 0.024 & -1.250 & $0.214^{\mathrm{NS}}$ \\
\hline 2. & Educational Qualification & 0.103 & 0.021 & 4.905 & 0.000 \\
\hline 3. & Working Experience & 0.073 & 0.02 & 3.650 & 0.000 \\
\hline 4. & Number of employees working in the company & -0.095 & 0.029 & -3.276 & 0.000 \\
\hline 5. & Annual Turnover & 0.124 & 0.029 & 4.276 & 0.000 \\
\hline & R Value & 0.919 & & & \\
\hline & $\mathbf{R}^{2}$ Value & 0.845 & & & \\
\hline & F Value & 20.762 & & & \\
\hline
\end{tabular}

Source: developed by the author.

Gap on Externalities $=-0.228-0.030$ (Age) +0.103 (Educational Qualification) +0.073 (Working experience) - 0.095 (Number of employees working in the company) +0.124 (Annual Turnover). It is found from the analysis that the educational qualification, working experience and annual turnover have positive association.

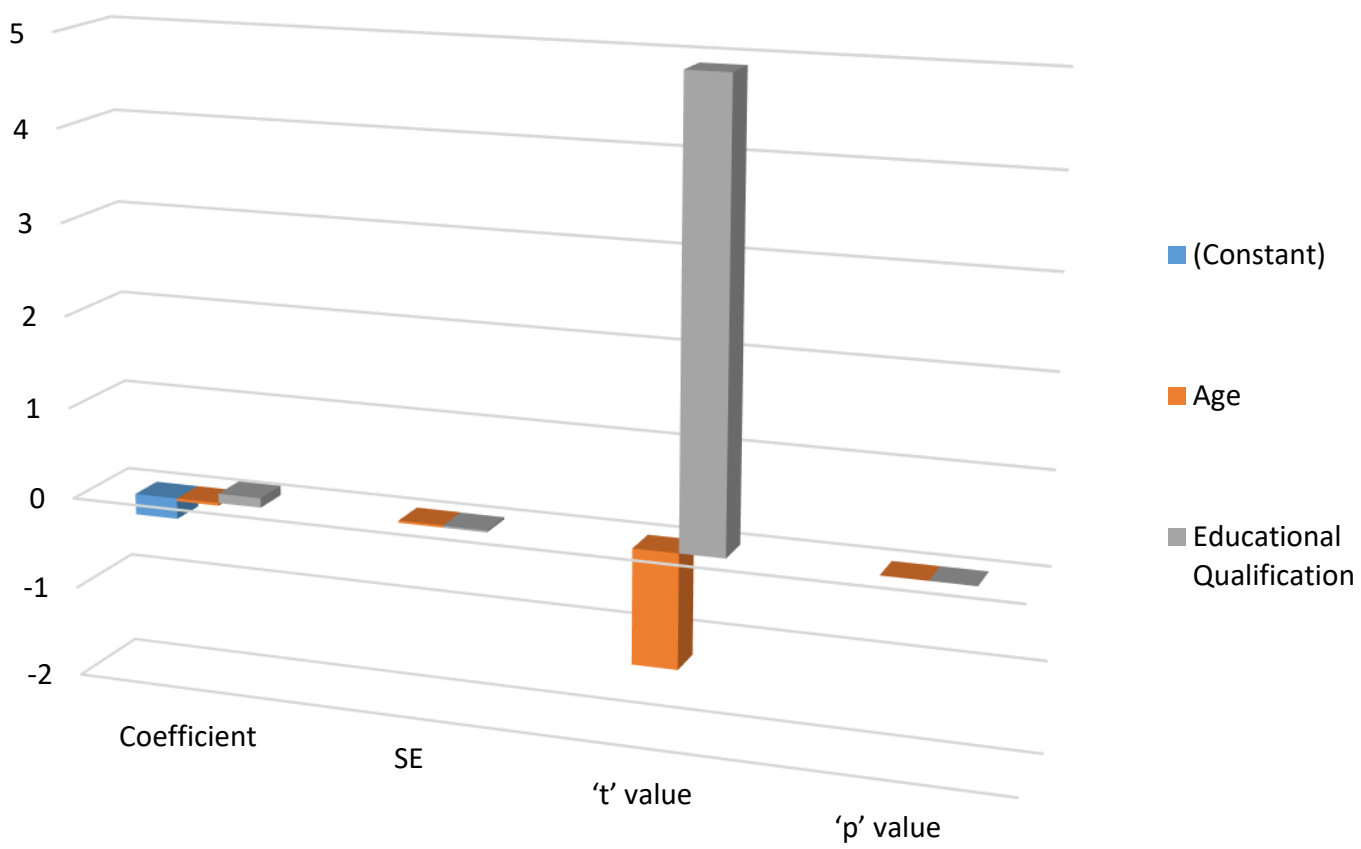

Figure 4. Externalities

Source: developed by the author on the basis of Table 4 . 
Table 5. The Gap in Perception and Expectation on Sustainable Production

\begin{tabular}{|c|c|c|c|c|c|}
\hline No. & Variables & Coefficient & SE & 't' value & 'p' value \\
\hline & (Constant) & -0.536 & & & \\
\hline 1. & Age & -0.004 & 0.025 & -0.160 & $0.880^{\mathrm{NS}}$ \\
\hline 2. & Educational Qualification & 0.113 & 0.021 & 5.381 & 0.000 \\
\hline 3. & Working Experience & 0.095 & 0.02 & 4.750 & 0.000 \\
\hline 4. & Number of employees working in the company & 0.118 & 0.03 & 3.933 & 0.000 \\
\hline 5. & Annual Turnover & -0.028 & 0.029 & -0.966 & $0.336^{\mathrm{NS}}$ \\
\hline & R Value & 0.981 & & & \\
\hline & $\mathbf{R}^{2}$ Value & 0.962 & & & \\
\hline & F Value & 71.799 & & & \\
\hline
\end{tabular}

Source: developed by the author.

Gap on Sustainable Production $=-0.536-0.004$ (Age) +0.113 (Educational Qualification) + 0.095 (Working experience) +0.118 (Number of employees working in the company) -0.028 (Annual Turnover). It is found from the analysis that the educational qualification, working experience and number of employees working in the company have positive association.

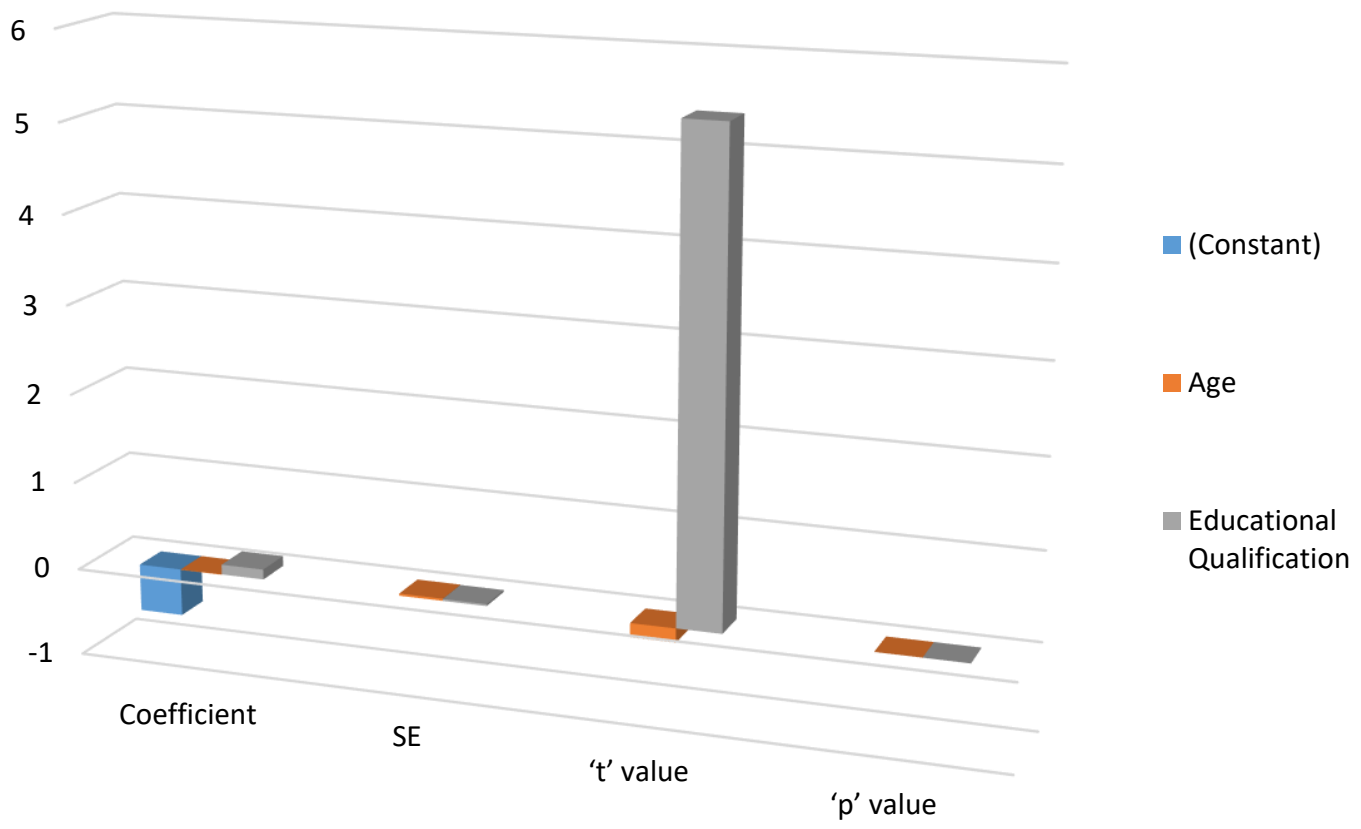

Figure 5. Sustainable Production

Source: developed by the author on the basis of Table 5. 
Table 6. The Gap in Perception and Expectation on Green Finance

\begin{tabular}{|c|c|c|c|c|c|}
\hline No. & Variables & Coefficient & SE & 't' value & 'p' value \\
\hline & (Constant) & -0.854 & & & \\
\hline 1. & Age & 0.113 & 0.026 & 4.346 & 0.000 \\
\hline 2. & Educational Qualification & -0.027 & 0.023 & -1.174 & 0.238 NS \\
\hline 3. & Working Experience & 0.201 & 0.022 & 9.136 & 0.000 \\
\hline 4. & Number of employees working in the company & -0.014 & 0.032 & -0.438 & $0.665^{\mathrm{NS}}$ \\
\hline 5. & Annual Turnover & 0.236 & 0.031 & 7.613 & 0.000 \\
\hline & R Value & 0.929 & & & \\
\hline & $\mathbf{R}^{2}$ Value & 0.863 & & & \\
\hline & F Value & 21.904 & & & \\
\hline
\end{tabular}

Source: developed by the author.

Gap on Green Finance $=-0.854+0.113$ (Age) -0.027 (Educational Qualification) +0.201 (Working experience) - 0.014 (Number of employees working in the company) +0.236 (Annual Turnover). It is found from the analysis that the age, working experience and annual turnover have positive association.

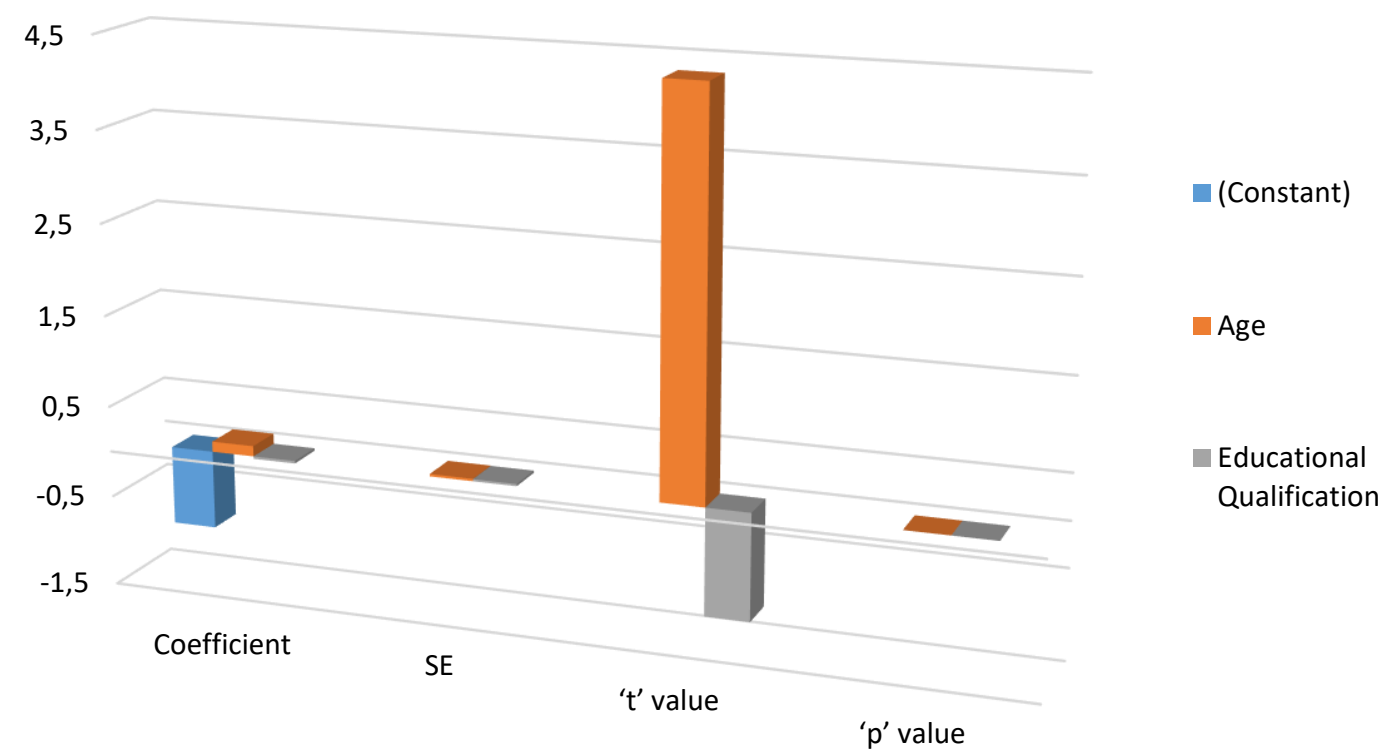

Figure 6. Green Finance

Source: developed by the author on the basis of Table 6 . 
Table 7. The Gap in Perception and Expectation on ESG Disclosures

\begin{tabular}{|c|c|c|c|c|c|}
\hline No. & Variables & Coefficient & SE & 't' value & 'p' value \\
\hline & (Constant) & -0.061 & & & \\
\hline 1. & Age & -0.054 & 0.026 & -2.122 & 0.034 \\
\hline 2. & Educational Qualification & -0.024 & 0.022 & -1.051 & $0.294^{\mathrm{NS}}$ \\
\hline 3. & Working Experience & -0.056 & 0.021 & -2.629 & 0.009 \\
\hline 4. & Number of employees working in the company & 0.006 & 0.031 & 0.191 & $0.849^{\mathrm{NS}}$ \\
\hline 5. & Annual Turnover & 0.119 & 0.030 & 3.967 & 0.000 \\
\hline & R Value & 0.926 & & & \\
\hline & $\mathbf{R}^{2}$ Value & 0.857 & & & \\
\hline & F Value & 32.863 & & & \\
\hline
\end{tabular}

Source: developed by the author.

Gap on ESG Disclosures $=-0.061-0.054$ (Age) -0.024 (Educational Qualification) -0.056 (Working experience) +0.006 (Number of employees working in the company) +0.119 (Annual Turnover). It is found from the analysis that the annual turnover has positive association.

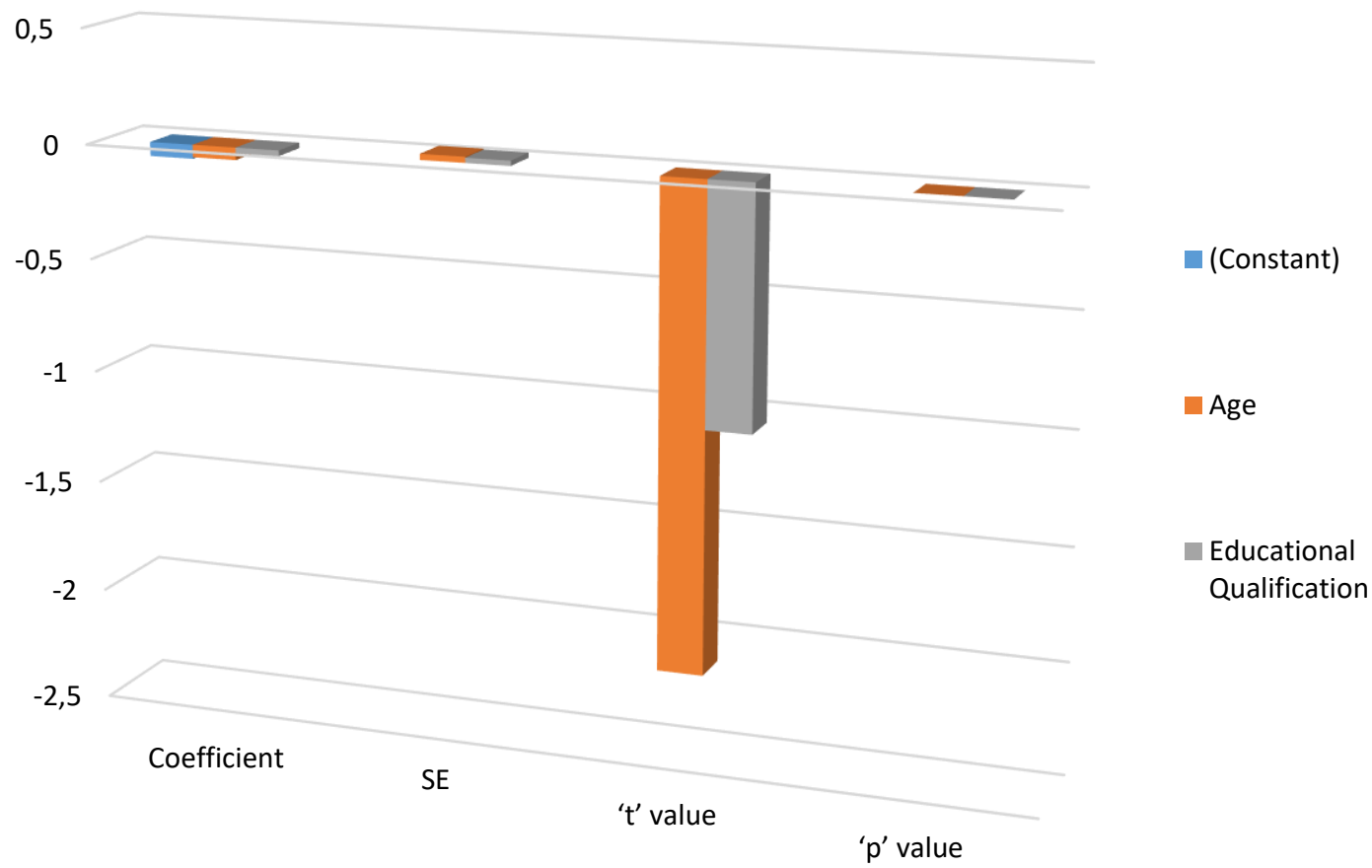

Figure 7. ESG Disclosures

Source: developed by the author on the basis of Table 7 . 
From the above results, it is noted that even though the small size enterprises have above 10year experience in their business they are expecting more of climate action. The government may provide financial as well as technical help to SMEs in order to ensure proper implementation of mandatory rules and regulations conforming to international standards. NGOs and their role and the consumer awareness can help in protecting the environment to a considerable extent that increases the chance of sustainable financing of SMEs.

It is noticed from the gap analysis that the perception of the SMEs is lesser than their expectation and hence a negative gap exists. The gap between the perception and expectation related to the profile of the SMEs has positive association in all seven sustainable financing components.

It is observed that regarding the sustainable financing for the installed capacity, production, and extent of demand, SMEs are unable to assess the present condition with the future prospects of their business and the mandatory requirements on ESG disclosures. So, it is recommended to the SMEs that they should understand all the facts of sustainable financing criteria and ESG disclosures sooner or later, which may qualify them and give more access to secure sustainable financing. Moreover, the sustainable financing of the SMEs would have to be transparent so as to make the sustainable finance providers decide on sustainable financing investments in a simple and easier way.

Sustainable finance and its mandatory sustainability practices and disclosures are the most important concern for SMEs to get necessary funding, on which there is no much awareness among the SMEs. It is recommended that financial education should be given to the SMEs by designing necessary modules for successful adaption of Sustainable financing requirements. It is also important to integrate mainstream SMEs for the growth of their business, but also to enrich their knowledge on sustainable financing through training and mentoring. These only can transform the SMEs and qualify them for sustainable financing application in future.

\section{Conclusion}

The flow of credit to SMEs in India has not kept pace with the growth of credit to non-SME sectors. By its sheer size, the SME market presents a huge opportunity for investors. But at present, the investors do not consider the whole of the SMEs credentials in the process of providing finance with the existing financial policy and regulations. In order to accommodate an improved version of SME financing incorporating sustainable financing criteria and ESG disclosures to make them qualified for sustainable financing for SMEs, it is necessary to install a better governance mechanism, strategies, risk management practices and metrics \& targets to plan and implement sustainable finance portfolio effectively in all parts of India. Moreover, this study has identified seven sustainable finance components and the UN SDGs to be considered for ascertaining the present level of understanding and awareness among the SMEs and to make them prepared for the future of sustainable financing to support their cause 
and purpose of getting hassle-free investment from the investors and to enhance the chance of making financing sustainable to SMEs.

In this regard, Government of India should take sustainable financing initiatives in association with the Reserve Bank of India and the stakeholders globally by taking suitable policy decisions for implementing seamless sustainable financing for SMEs. Government would have to act fast as there is a compelling situation to fulfil the state obligations on sustainable financing portfolio considering the time required for the SMEs to align themselves to the financial market requirements. It becomes necessary for SMEs to work closely with financial institutions and investors, governments, SME associations and international institutions. Obviously, the organisation of this paper is forward looking and helps maximize the sustainability adaption for securing finance for the development of SMEs to further strengthen their present state. The role of the stakeholders is to be structured to provide more exposure on vital factors related to business sustainability with a more holistic approach to sustainable financing, financial policy and strategic fund raising and allocations across the sustainable finance ecosystem locally and internationally.

\section{References}

Acemoglu, D., \& Robinson, J. A. (2012). Why Nations Fail: The Origins of Power, Prosperity, and Poverty. New York: Crown Publishers.

Angilella, S., \& Mazzù, S. (2013). The Financing of Innovative SMEs: a multi-criteria credit rating model. European Journal of Operational Research, 244(2), 540-554. https://doi.org/10.1016/j.ejor.2015.01.033

Ayyagari, M., Demirguc-Kunt, A., \& Maksimovic, V. (2012). Financing of firms in Developing Countries. Policy Research Working Paper 6036. Washington DC: The World Bank.

Beck, T., Demirguc-Kurt, A., \& Maksimovic, V. (2008). Financing Patterns around the World: Are Small Firms Different? Journal of Financial Economics, 89(3), 467-487.

Brandt, P., Ernst, A., Gralla, F., Luederitz, C., Lang, D., Newig, J., Reinert, F., Abson, D., Von Wehrden, H. (2013). A review of transdisciplinary research in sustainability science. Ecological Economics, 92, 1-15. https://doi.org/10.1016/j.ecolecon.2013.04.008

Busch, T., Bauer, R., \& Orlitzky, M. (2016). Sustainable Development and Financial Markets: Old Paths $\begin{array}{llll}\text { and New Avenues. Business \& Society, 55(3), 303-329. } & \text {. }\end{array}$ https://doi.org/10.1177/0007650315570701

Calice, P., Chando, V.M., \& Sekioua, S. (2012). Bank Financing to Small and Medium Enterprises in East Africa: Findings of a Survey in Kenya, Tanzania, Uganda and Zambia. Working Paper No. 146. Tunis, Tunisia: African Development Bank Group. 
Chava, S. (2014). Environmental externalities and cost of capital. Management Science, 60(9), 222347. http://dx.doi.org/10.1287/mnsc.2013.1863

Chimucheka, T. (2013). Obstacles to Accessing Finance by Small Business Operators in the Buffalo City Metropolitan Municipality. East Asian Journal of Business Management, 3(2), 23-29. https://doi.org/10.13106/eajbm.2013.vol3.no2.23

Dalal, K. K., \& Thaker, N. (2019). ESG and Corporate Financial Performance: A Panel Study of Indian Companies. The IUP Journal of Corporate Governance, 18(1), 44-59.

Hamilton, R.T., \& Fox, M.A. (1998). The financing preferences of small firm owners. International Journal of Entrepreneurial Behaviour \& Research, 4(3), 239-248. https://doi.org/10.1108/13552559810235529

Hopwood, B., Mellor, M., \& O’Brien, G. (2005). Mapping Different Approaches. Sustainable Development., 13(1), 38-52. https://doi.org/10.1002/sd.244

Jain, S. C. (1990). Book Reviews on Development programmes of urban poor. Indian Journal of Public Administration, 36(2), 358-360. https://doi.org/10.1177/0019556119900226

Lang, D.J., Wiek, A., Bergmann, M., Stauffacher, M., Martens, P., Moll, P., Swilling, M., Thomas, C.J. (2012). Transdisciplinary research in sustainability science: Practice, principles, and challenges. Sustainability Science, 7, 25-43. https://doi.org/10.1007/s11625-011-0149-x

Mercieca, S., Schaeck, K., \& Wolfe, S. (2009). Bank Market Structure, Competition, and SME Financing Relationships in European Regions. Journal of Financial Services Research, 36, 137-155.

Pascual, J. (2021). Rio +20 and Culture: Advocating Culture as a Pillar of Sustainability. Barcelona, Spain: UCLG - United Cities and Local Governments. Retrieved from https://www.uclgcisdp.org/sites/default/files/Rio20_ENG_def\%2B\%25281\%2529.pdf

Sandberg, J. (2015). Toward a Theory of Sustainable Finance. Geneva, Switzerland: Inquiry: Design of a Sustainable Financial System, International Environment House.

Schoenmaker, D. (2017). From Risk to Opportunity: a Framework for Sustainable Finance. RSM Positive Change Series. Rotterdam, the Netherlands: Rotterdam School of Management (RSM), Erasmus University. Retrieved from http://hdl.handle.net/1765/101671

Schoenmaker, D., \& Schramade, W. (2018). Principles of Sustainable Finance. Oxford: Oxford University Press.

Scholtens, B. (2006). Finance as a Driver of Corporate Social Responsibility. Journal of Business Ethics, 68, 19-33. https://doi.org/10.1007/s10551-006-9037-1

Storey, D. J., (1994). Understanding the small business sector. 1st Edition. London: Routledge. https://doi.org/10.4324/9781315544335

Vegholm, F. (2009). Understanding Bank-SME Relationships: The Influence of Adaptation and Fairness on Customer Satisfaction. Stockholm: Centrum för bank och finans. 
Zabri, S.M., Ahmad, K., Adonia, S.A., \& McMillan, D. (2021). The influence of managerial characteristics on external financing preferences in smaller enterprises: The case of Malaysian micro-sized enterprises. Cogent Business \& https://doi.org/10.1080/23311975.2021.1912524 